\title{
Does Increasing Public Hospital Financial Autonomy Improve Performance? A Study of Indonesian Public Hospitals
}

\author{
Fitri HANDAYANI \\ Hasan BASRI' \\ Heru FAHLEVI ${ }^{3}$
}

\begin{abstract}
This study aims to compare the financial and non-financial performance of Indonesian public hospitals after gaining improved autonomy in financial management (Badan Layanan umum/ $B L U$ or Public Service Agency/ PSA). It is conducted in two public hospitals in Banda Aceh City, Indonesia. Qualitative research design and descriptive analysis were undertaken to obtain a clearer picture of the performance and to provide a comparative analysis. The financial performance analysis is measured by using trend analysis, profitability ratio, cost recovery rate, and independence level. The non-financial performance analysis is measured by using BOR (Bed Occupancy Ratio), TOI (Turn over Interval), BTO (Bed Turn Over), ALOS (Average Length of Stay), GDR (Gross Death Rate), and NDR (Net Death Rate). The results show divergent results. There is an increase in revenue and profit after gaining BLU, but profitability, cost recovery rate, and independence level have decreased. The ratios of BOR, TOI, and NDR after BLU has changed slightly. However, the BTO, ALOS, and GDR after BLU are far above the criteria/standard of hospital service performance.
\end{abstract}

KEYWORDS: Public Service Agencies, Financial Performance, Non-financial Performance Public hospitals

JEL CLASSIFICATION: H51.

\section{INTRODUCTION}

Hospital sector has been targeted for efficiency through serial of reforms. The reforms have been carried out not only in developed countries but also in developing countries. In this context, Indonesia has started health care sector reforms since the last decades including the arrangement of public sectors. At least, there are two main reforms in Indonesian public hospitals, namely the transformation of public hospitals into a more business-like hospitals under the (Badan Layanan umum/ BLU or Public Service Agency/ PSA) and the adoption of Diagnostic Related Groups based payment system (Fahlevi, 2016).

The increased financial autonomy under BLU/PSA status has an objective to improve the government institution performance. Finally, the managers of the BLU have the motivation to manage and allocate collected revenues as the money are not transferred to the local government anymore. They can use the money for purchasing the required facilities and increasing staff bonus. In public hospitals, the BLU/ PSA status can ensure the availability of medicines and other supporting material for health care services.

\footnotetext{
${ }^{1}$ Syiah KualaUniversity, Aceh, Indonesia, ipiet.handayani@yahoo.com ${ }^{2}$ Syiah KualaUniversity, Aceh, Indonesia, P haasan@unsyiah.ac.id ${ }^{3}$ Syiah KualaUniversity, Aceh, Indonesia, hfahlevi@unsyiah.ac.id
} 
A BLU is an agency within the government that established to provide services to the community in the form of goods and/or services sold without prioritizing profit, such as hospital and educational institutions. One of the characteristics of BLU is an institution can be managed autonomously with the principle of corporate efficiency and productivity. It is important to note that the introducing the concept of BLU is part of the reform of the Indonesian public sector which was initially implemented in the early 1980s and 1990s in line with the wave of new public management (NPM) across the globe (Jurnali \& Nabiha, 2015).

Public hospitals in Indonesian have been forced to transform into a BLU/ PSA hospital. The main objectives are to increase the service quality and financial independence of public hospitals. However, previous studies documented unexpected results. Fahlevi (2016) conducted a multiple case study on the Indonesian public hospitals' response to reforms. $\mathrm{He}$ found that the BLU status did not provide a strong motivation of the studied public hospitals to respond properly to the new adopted Indonesian DRGs payment system. Moreover, more recent studies carried out by Rawung and Sholihin (2017) in health care centers (Puskesmas) documented a better performance of BLUD-Puskesmas than the non-BLUD Puskesmas.

A hospital as one type of BLU (Public Service Agencies) is the spearhead in the development of public health. To be able to provide quality services, hospitals require good financial management. The status of BLU does not always increase the business motivation of hospitals (Fahlevi, 2016). The performance of puskesmas (community health centres) after gaining a BLU is also influenced by human resources, facilities and support from the health office, the local government and the legislative institution (Rawung \& Sholihin, 2017). Research on hospitals after gaining BLU is limited.

The purpose of this study is to find out how the status BLUD improves the financial performance and non-financial performance/service performance, elaborate supporting factors/inhibitors of performance improvement after gaining a BLUD. Another purpose is to get a wider overview of performance achievement at the local government hospital as a BLUD. The rest of the paper is organized as follows: Section 2 review the selected literature, section 3 discuss the research method used, followed by section 4 that provides findings and discussion. Section 5 provides conclusions and suggestions

\section{LITERATURE REVIEW}

Permendagri (Regulation of the Minister of Home Affairs) No.61 Year 2007 in Chapter 1 of Article 1 Paragraph 1 explains that the Local Public Service Agency hereinafter abbreviated as BLUD is the Local Government Work Unit within the Regional or Local Government which is established to provide services to the public in the form of the provision of goods and/or services sold without prioritizing profits, and in carrying out its activities based on the principles of efficiency and productivity. In article 1 point (2) of this Regulation explains that the BLUD Financial Management Pattern, hereinafter in short PPK-BLUD is a financial management pattern that provides flexibility to apply sound business practices to improve services to the public in order to advance the general welfare and intellectual life of the nation, as an exception to the provisions of regional financial management in general.

To become a BLU, it must meet the requirements as stipulated in Article 4 of Government Regulation of the Republic of Indonesia no. 23 of 2005, as follows: the first is the substantive requirement: government agency provides public services in the form of providing goods 
and/or services, managing special funds, or supervising the region. The second is the technical requirement: service performance in the area of main tasks and functions of government agencies is feasible to be managed and enhanced through BLU, and it has healthy financial performance. The third is the administrative requirements. If the first and second requirements have been met, the technical minister proposes the agency / work units with regard to the Minister of Finance for assessment through administrative requirements documents, namely: (1) Statement of ability to improve performance; (2) Pattern of Governance; (3) Business Strategic Plan; (4) Principal Financial Statement; (5) Minimum Service Standards (MSS); and (6) The latest audited report or a statement of willing to be audited (Directorate of PPK-BLU, 2014).

The development of financial management is based on the Regulation of the Minister of Home Affairs No. 59 of 2007 on the Amendment of the Regulation of the Government of Home Affairs No. 13 of 2006 on the Financial Management Manual for Local Government. The Regulation of the Minister of Home AffairsNo.59 of 2007 is almost the same as No.13 of 2006. The only difference between the two regulations is that some of the articles contained in the regulation No.13 of 2006 are removed and no longer valid.

The differences in financial management before and after the implementation of BLUD lies on the work unit that has the status of BLUD which is given the flexibility to manage their money, including the direct use of all Non-Tax Revenue (PNBP) from the operating revenue of the BLUD without firstly depositing into the State Treasury account. The funds (PNBP) are not included in APBN or State Budget (Regulation of the Director General of Treasury No.50, 2007).

Performance is something that has been achieved by the organization within a certain time, both related to input, output, outcome, benefit, and impact (Sobandi \& Artyasa, 2006:176). The work achieved by employees of an agency in carrying out its duties in a certain period of time, whether related to input, output, outcome, benefit and impact attached with the responsibility, can facilitate the direction of structuring the government organization. The existence of the work with full responsibility will achieve effective and efficient performance improvement.

Performance evaluation aims to measure the level of achievement of BLUD management outcomes as defined in the business strategic plan and business budget. Performance evaluation from financial aspect can be measured based on BLUD capability level in a) obtaining business result or work result from service given (profitability), b) fulfilling its short-term liabilities (liquidity), c) fulfilling all liabilities (solvency), and d) the ability to earn to finance expenditures.

Performance evaluation applies not only to profile-oriented institutions but also to noncommercial organizations. Financial performance is an important factor for assessing the overall performance of the organization or organizational condition. The performance of puskesmas (health care center) after the implementation of the Financial Management Pattern of Regional Public Service Agency (PPK BLUD) showed an increase in performance after two and a half years. The financial aspect has an average performance value lower than the service aspect and the benefit aspect of the community (Rawung \& Sholihin, 2017).

A study conducted by Fahlevi (2016) at two state-owned hospitals in Jakarta Province found that the application of the case base payment system was not followed by changes in 
accounting practices at both hospitals. The hospital management does not have a specific strategy to develop a more complex cost accounting system in responding to payment systems through CBGs. The management also felt that financial issues are not their responsibility and the hospital owner will cover the hospital's deficit or losses.

\section{RESEARCH METHODS}

This research is qualitative research. According to Sugiyono (2012, 2014), a qualitative method is often called a naturalistic method because the research is done on natural conditions (natural settings). The research was carried out at two local Government Hospitals in Banda Aceh city, the capital of Aceh Province. This city can represent cities and regencies in Aceh province and it has all types of hospital. The object of this study is hospitals that were established before the year 2010 because BLU status began to apply since 2010, and whose data is accessible.

The data in this study comes from primary and secondary data. Data collection techniques used 2 (two) methods, namely interview to obtain primary data, and documentation to obtain secondary data. This study used semi-structured interviews. List of hospitals that became the object of research can be seen in the table below.

Table 1. List of hospitals

\begin{tabular}{|c|l|c|c|c|}
\hline NO & \multicolumn{1}{|c|}{ HOSPITALS } & TYPE & OWNERSHIP & LOCATION \\
\hline 1 & King Hospital* & A & Province Aceh & Banda Aceh \\
\hline 2 & Queen Hospital* $^{*}$ & B & Province Aceh & Banda Aceh \\
\hline
\end{tabular}

*These are not the real name of the hospitals. The original names are hidden at the request of the institutions.

The profile of the hospitals can be seen in the table below.

Table 2. The profile of the hospitals

\begin{tabular}{|c|c|c|c|c|}
\hline \multirow{2}{*}{ No } & \multirow{2}{*}{ Hospitals } & \multicolumn{3}{|c|}{ Profile } \\
\cline { 3 - 5 } & & Number of specialist doctors & Number of general doctors & Total beds \\
\hline 1 & King Hospital & 168 & 41 & 514 \\
\hline 2 & Queen Hospital & 15 & 30 & 463 \\
\hline
\end{tabular}

Financial indicators and non-financial indicators, a part of the secondary data, can be seen in the tables below.

Table 3. Financial indicators

\begin{tabular}{|c|l|c|c|}
\hline No & Financial indicators & Formula & \\
\hline 1 & NPM (Profitability) & NPM $=$ (profit aftertax/total assets) x 100\% & NPM : Net Profit Margin \\
\hline 2 & CRR & CRR = Tariff / Unitcost x 100\% & CRR : Cost Recovery rate \\
\hline 3 & Level ofindependence & $\begin{array}{c}\text { RK = Locally-generatedrevenue / } \\
\text { governmentassistancefundsandloans }\end{array}$ & RK:level ofindependence \\
\hline
\end{tabular}

Source: authors 
Table 4. Non-financial indicators

\begin{tabular}{|c|c|c|c|}
\hline No & $\begin{array}{l}\text { Non-financial } \\
\text { indicators }\end{array}$ & Formula & \\
\hline 1 & BOR & $\begin{array}{c}\text { BOR }=\text { total daysofstay } /(\text { total bedsxnumberofdays in } \\
\text { a period }) \times 100 \%\end{array}$ & BOR:BedOccupancyRatio \\
\hline 2 & TOI & $\begin{aligned} \text { TOI }= & ((\text { total beds } x \text { periods })-\text { total daysofstay })) \\
& : \text { total numberofdischarges (live }+ \text { die })\end{aligned}$ & TOI : Turn Over Interval \\
\hline 3 & BTO & $\mathrm{BTO}=$ total numberofdischarges: total beds & BTO:BedTurn Over \\
\hline 4 & ALOS & $\begin{array}{l}\mathrm{ALOS}=\text { total daysofstay/the } \\
\text { totalnumberofdischarges }\end{array}$ & ALOS:AverageLengthofStay \\
\hline 5 & NDR & $\begin{array}{l}\mathrm{NDR}=(\text { numberofdeath over } 48 \text { hours : } \\
\text { numberofdischarges }(\text { live }+ \text { die }) \text { ) } 1000\end{array}$ & NDR : Net Death Rate \\
\hline 6 & GDR & $\begin{array}{l}\mathrm{GDR}=\text { (numberofalldeath / total } \\
\text { numberofdischarges }) \times 1000\end{array}$ & GDR : GrossDeath Rate \\
\hline
\end{tabular}

Source: authors

This study used semi-structured interviews to gather detailed information on the impact of BLUD status on hospital performances (see table 5).

Table 5. Study information

\begin{tabular}{|l|l|}
\hline \multicolumn{1}{|c|}{ Activity } & \multicolumn{1}{c|}{ Informants } \\
\hline Interview & $\begin{array}{l}\text { - Director of Local Government Hospital of Banda Aceh City } \\
\text { - Head of the Hospital Medical Service } \\
\end{array}$ \\
& Head of Accounting subsection and staffs.
\end{tabular}

Source: authors

\subsection{Data Analysis Method}

The data is analyzed by using the quantitative descriptive method. It started with collecting data related to the analysis of financial and non-financial performance before and after BLU at the hospitals. The data analysis process begins with collecting secondary data that is financial data of Local Government Hospitals which consist of profitability ratio, cost recovery rate, and independence level, then collecting non-financial performance data relating to BOR, TOI, BTO, ALOS, GDR and NDR.

\section{RESEARCH RESULT}

\subsection{Financial Performance Analysis of King Hospital Before and After gaining BLU}

At this stage, trend analysis is performed to test the level of changes in assets, revenue and profits at the King hospital. In summary, trend analysis results from the financial data of King Hospital before and after BLU can be stated as follows: 


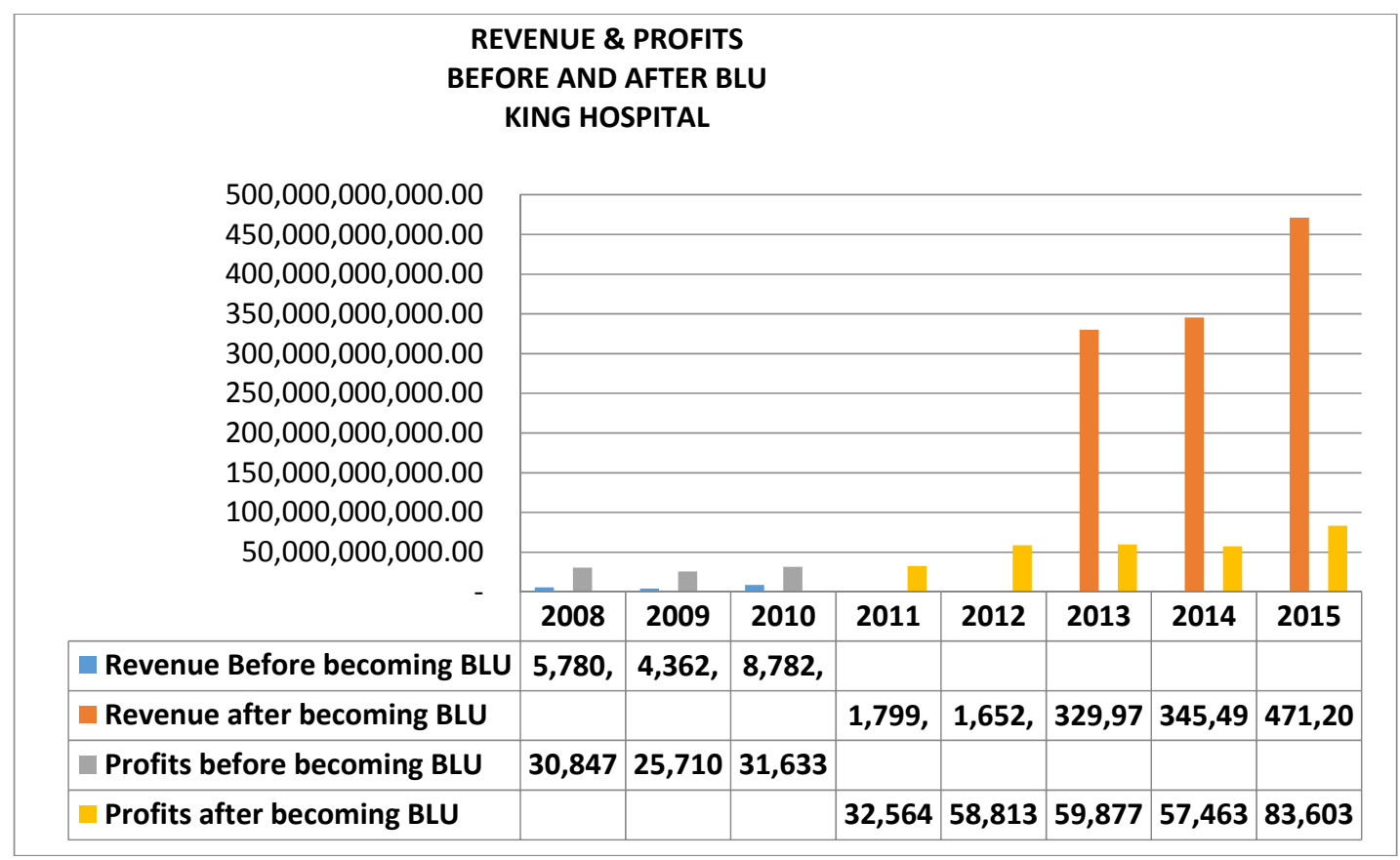

Figure 1. Revenue and Profits of King Hospital

Source: Financial Report of King hospital 2008-2015

Based on the graph as shown in Figure 1, it can be stated the revenue and profit of King Hospital both before and after BLU tend to increase. Revenue of King hospital increased due to an increase in the number of patients, especially public health insurance patients that ultimately leads to an increase in hospital revenue. While the increase in this profit indicates that the King hospital earns more revenue than expenditure.

The financial performance indicators of King Hospital are presented in table 6 below:

Table 6. Comparison of Financial Performance of King Hospital before and after BLU Implementation

\begin{tabular}{|c|c|c|c|c|c|c|c|c|c|c|}
\hline \multirow{2}{*}{ No. } & \multirow{2}{*}{ Indicator } & \multicolumn{2}{|c|}{ Before BLU (\%) } & \multicolumn{6}{|c|}{ After BLU (\%) } & \multirow{2}{*}{$\begin{array}{c}\text { Change } \\
(\%)\end{array}$} \\
\hline & & 2008 & 2009 & 2010 & 2011 & 2012 & 2013 & 2014 & 2015 & \\
\hline 1 & Profitability & 11.88 & 22.98 & 17.12 & 6.40 & 5.70 & 5.07 & 4.51 & 4.02 & -10.29 \\
\hline 2 & Cost Recovery Rate & 118.66 & 76.77 & 98.87 & 75.66 & 67.34 & 59.93 & 53.34 & 47.47 & -30.61 \\
\hline 3 & Level of Independence & 82.12 & 53.22 & 67.89 & 52.33 & 46.57 & 41.45 & 36.89 & 32.83 & -21.34 \\
\hline
\end{tabular}

Table 6 shows a big picture of the financial performance of King Hospital before and after gaining BLU. First, the ratio of profitability is used to measure the profit derived from the capital used in the operation (Munawir, 2001: 86). The size of the profitability depends on the profit earned and the capital held in running the business. Second, The Cost Recovery Rate (CRR) is a value in the percentage that indicates the hospital's ability to cover its expenditure with its patient-generated revenue (retribution). Third, the level of independence is a ratio that shows the ability of hospitals to finance the entire expenditure by itsrevenue.

The result shows that the profitability ratio measured by the indicator in the period before becoming BLU has an average score of $17.43 \%$ and after BLU $7.14 \%$ which results in a decrease of $10.29 \%$. The result also described that the Cost Recovery Rate in the period 
before BLU obtained an average value of $97.72 \%$, while after BLU the average score is $67.10 \%$ which results in a decrease of $30.62 \%$. A good Cost Recovery Rate is above $100 \%$ which means that the revenue earned is able to cover all expenses and has already made a profit. The results of this study indicate that the Cost Recovery Rate is still below 100\% which means that the level of cost recovery on hospital services has not been achieved and the revenue earned has not been able to cover the expenditure.

The results shows that the independence level in the period before BLU has an average value of $67.67 \%$, while after BLU is $46.33 \%$ which results in a decrease of $21.34 \%$. The independence level reflects the ability of the hospital in fulfilling all operating expenses from operating revenue. The revenue continues to increasebut the operational expenses continue to increase. The substantial increase in operating expenditures was not followed by a significant increase in operating revenue which contributed to the decline in the level of independence.

\subsection{Non-Financial Performance Analysis of King Hospital Before and After gaining BLU}

Assessment of hospital performance at this stage is an assessment of non-financial aspects. According to the Regulation of the Minister of Home Affairs No. 61 of 2007, performance measurement from non-financial aspects can be done through internal service process. According to the Ministry of Health of the Republic of Indonesia, 2005 the quality of services provided by a hospital can be identified from several indicators such as BOR, TOI, BTO, ALOS, GDR, and NDR.

The criteria/standard of hospital service performance measurement, as determined by the Director General of Medical Services of the Indonesian Ministry of Health Year 2005, can be seen in table 7.

Table 7. Criteria / Standard Measurement of Hospital Service Performance

\begin{tabular}{|l|l|l|l|}
\hline No. & Service Indicators & $\begin{array}{l}\text { Standards from the Department of Health of Indonesia } \\
(\mathbf{2 0 0 5})\end{array}$ & Criteria \\
\hline 1 & BOR & $60-85 \%$ & Good \\
\hline 2 & TOI & $1-3$ days & Good \\
\hline 3 & BTO & $40-50$ times & Good \\
\hline 4 & ALOS & $6-9$ days & Good \\
\hline 5 & GDR & Not more than 45/1000 discharges & Good \\
\hline 6 & NDR & Less than 25/1000 discharges & Good \\
\hline
\end{tabular}

Source: Director General of Medical Services, Ministry of Health, Republic of Indonesia, 2005

Based on the results of data collection related to the non-financial indicator in this hospital in the period before and after BLU shown in table 8:

Table 8. Comparison of Non-Financial Performance of King Hospital at before and after gaining a public service agency

\begin{tabular}{|c|c|c|c|c|c|c|c|c|c|c|c|c|c|}
\hline \multirow{2}{*}{ No. } & \multirow{2}{*}{ Indicator } & \multicolumn{2}{|c|}{$\begin{array}{c}\text { Before BLU } \\
(\%)\end{array}$} & \multicolumn{6}{|c|}{ After BLU (\%) } & \multirow{2}{*}{\begin{tabular}{|c|} 
Average \\
Before \\
BLU \\
$(\%)$ \\
\end{tabular}} & \multirow{2}{*}{$\begin{array}{c}\text { Average } \\
\text { After } \\
\text { BLU } \\
(\%) \\
\end{array}$} & \multirow{2}{*}{$\begin{array}{c}\text { Criteria } \\
\text { Before } \\
\text { BLU }\end{array}$} & \multirow{2}{*}{$\begin{array}{c}\text { Criteria } \\
\text { After } \\
\text { BLU }\end{array}$} \\
\hline & & 2008 & 2009 & 2010 & 2011 & 2012 & 2013 & 2014 & 2015 & & & & \\
\hline 1 & BOR $(\%)$ & 88.90 & 89.79 & 92.60 & 78.33 & 80.24 & 82.32 & 84.77 & 86.81 & 85.28 & 84.18 & Good & Good \\
\hline 2 & TOI (days) & 0.20 & 0.40 & 0.50 & 0.70 & 0.60 & 0.55 & 0.50 & 0.48 & 0.49 & 0.56 & Moderate & Moderate \\
\hline 3 & BTO (times) & 50.00 & 50.00 & 80.00 & 90.00 & 92.00 & 91.00 & 92.00 & 93.00 & 77.86 & 89.67 & Good & Good \\
\hline 4 & ALOS (days) & 2.00 & 3.00 & 4.00 & 3.00 & 3.00 & 2.00 & 2.00 & 2.00 & 2.71 & 2.67 & Moderate & Moderate \\
\hline 5 & GDR (\%) & 4.00 & 3.00 & 5.00 & 4.00 & 5.00 & 4.00 & 4.00 & 4.00 & 4.14 & 4.33 & Good & Good \\
\hline 6 & NDR (\%) & 1.44 & 0.77 & 1.98 & 1.23 & 1.13 & 1.08 & 1.02 & 0.87 & 1.24 & 1.22 & Good & Good \\
\hline
\end{tabular}


From the above data, it can be stated that the non-financial performance of King hospital is considered good for this BOR indicator both in the period before and after gaining a BLU. Despite the downturn after BLU, the BOR score has proven to be consistent with the criteria set by the Ministry of Health of the Republic of Indonesia, which is between $60 \%-85 \%$.Such a good BOR score indicates that the number of treated patients does not exceed the available bed capacity.

The indicator of TOI in the period before BLU cannot be categorized as good because it does not meet the criteria/standard but after BLU it can be categorized as good. This indicates that the utilization of bed in King Hospital is efficient. In the period after BLU, the bed is not used averagely in 1 day and in the period before BLU the average day in which the bed is not used is less than 1 day.

The BTO of King hospital in the period before BLU and after BLU cannot be considered as good because it does not meet the standard which is between 40-50 times that has been set by the ministry. The result shows that the average efficiency rate of bed usage is still not good. The high score of BTO is influenced by the increasing number of inpatients of RS King and this ratio compares the number of patients discharged (live and dead) compared with the number of beds. The more the number of patients, the more the number of patients discharged.

ALOS of King hospital cannot meet the criteria/standard. The standard of hospital service performance measurement for ALOS is 6-9 days but the ALOS of this hospital is 3 days for both before and after BLU. This means that King Hospital is considered not to have good efficiency and cannot perform a good quality service.

GDR of King hospital is generally good because they are still within the criteria/standards. By looking at table 4.3, the GDR is still on the criteria/standard of the performance measurement.

The score of NDR of King hospital already meets standards. The standard of NDR is less than 25 patients for every 1000 patients. In general, the main cause of this high NDR is almost the same as the case for GDR which is care services that are considered to have met the standard so that the death rate becomes low. This NDR can better reflect the quality of service at the King Hospital, because the NDR rate is based on the number of deaths over 48 hours, unlike the GDR which is based on the number of all deaths that often cause bias. Many patients rushed to the hospital died before 48 hours of treatment.

\subsection{Financial Performance Analysis of Queen Hospital Before and After gaining BLU}

Trend analysis is performed to test the level of changes in assets, revenue, and profits at Queen Hospital. In summary, the trend analysis before and after BLU can be figured as follows: 


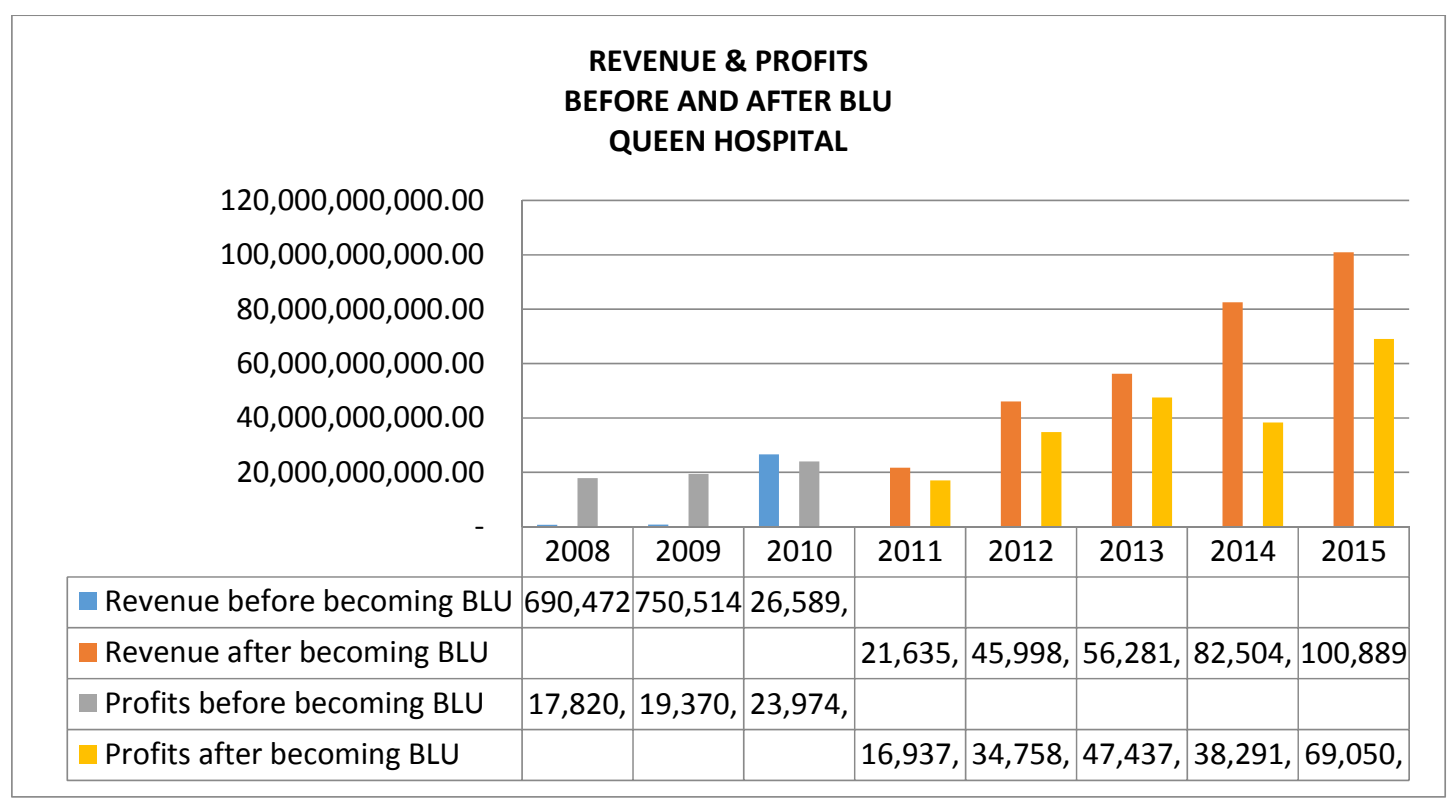

Figure 2. Graph of Revenue \& Profit of Queen Hospital

Source: Financial Report of Queen Hospital (2008-2105)

Based on Figure 2 it can be stated that the revenue and profit of Queen Hospital before and after BLU tend to increase. The revenues increase due to an increase in the number of patients served, especially public health insurance patients, which ultimately led to an increase in hospital revenues. The increase in profits indicates that the hospital earns more revenue than bill payment.

Table 9. Indicators before BLU and after BLU

\begin{tabular}{|c|c|c|c|c|c|c|c|c|c|c|}
\hline \multirow[t]{2}{*}{ No } & \multirow{2}{*}{ Indicators } & \multicolumn{2}{|c|}{$\begin{array}{c}\begin{array}{c}\text { Before BLU } \\
(\%)\end{array} \\
\end{array}$} & \multicolumn{6}{|c|}{ After BLU (\%) } & \multirow{2}{*}{$\begin{array}{c}\text { Changes } \\
(\%)\end{array}$} \\
\hline & & 2008 & 2009 & 2010 & 2011 & 2012 & 2013 & 2014 & 2015 & \\
\hline 1 & Profitability Ratio & 6.88 & 17.98 & 12.12 & 10.79 & 9.60 & 8.54 & 7.60 & 6.77 & -3.19 \\
\hline 2 & Cost $\mathrm{F}$ & 113.66 & 71.77 & 93.87 & 83.54 & 74.35 & 66.18 & 58.90 & 52.42 & -21.17 \\
\hline 3 & Level of independence & 77.12 & 48.22 & 62.89 & 55.97 & 49.82 & 44.34 & 39.46 & 35.12 & -14.74 \\
\hline
\end{tabular}

Based on table 9 the profitability level indicates the ability of an organization to earn revenue from giving services. The results showed that the profitability ratio in the period before BLU was averagely $12.43 \%$, while after BLU was averagely $9.24 \%$ which results in a decrease of $3.19 \%$.

Cost Recovery Rate indicates the ability of the hospital to meet all functional spending from the operating revenue. The result shows that the Cost Recovery Rate in the period before BLU was $92.72 \%$ on average, while after BLU was $71.54 \%$ on average which results in a decrease of $21.81 \%$. The Cost Recovery Rate ratio reflects there venue obtained and the functional expenditure paid by the hospital. The result indicates that the Cost Recovery Rate is still below $100 \%$ which means that the level of cost recovery of hospital services is still not reached. In this case. the revenue cannot cover the cost to provide services.

The independence level shows the ability of the hospital to meet all operating expenses from operating revenue. The independence ratio reflects the revenue obtained and the operational expenditure paid by the hospital. The operating revenue has increased but the operating 
expenses have increased as well. The substantial increase in operating expenditures was not followed by a significant increase in operating revenue which contributed to the decline in the level of hospital independence.

\subsection{Non-Financial Performance Analysis of Queen Hospital Before and After gaining BLU}

Comparison of Non-Financial Performance of Queen Hospital before and after gaining a BLU

Table 10. Comparison of Non-Financial Performance of Queen Hospital at before and after gaining a public service agency

\begin{tabular}{|c|c|c|c|c|c|c|c|c|c|c|c|c|c|}
\hline \multirow{2}{*}{ No. } & \multirow{2}{*}{ Indicator } & \multicolumn{2}{|c|}{ Before BLU (\%) } & \multicolumn{6}{|c|}{ After BLU (\%) } & \multirow{2}{*}{$\begin{array}{l}\text { Average } \\
\text { before } \\
\text { BLU }(\%)\end{array}$} & \multirow{2}{*}{$\begin{array}{c}\text { Average } \\
\text { after } \\
\text { BLU (\%) }\end{array}$} & \multirow{2}{*}{$\begin{array}{c}\text { Category } \\
\text { before } \\
\text { BLU }\end{array}$} & \multirow{2}{*}{$\begin{array}{l}\text { Category } \\
\text { after BLU }\end{array}$} \\
\hline & & 2008 & 2009 & 2010 & 2011 & 2012 & 2013 & 2014 & 2015 & & & & \\
\hline 1 & BOR $(\%)$ & 71.12 & 71.83 & 74.08 & 62.66 & 64.19 & 65.86 & 67.82 & 69.45 & 71.48 & 67.34 & Good & Good \\
\hline 2 & TOI (days) & 0.16 & 0.32 & 0.40 & 0.56 & 0.48 & 0.44 & 0.40 & 0.38 & 0.24 & 0.44 & Moderate & Moderate \\
\hline 3 & $\begin{array}{l}\begin{array}{l}\text { BTO } \\
\text { (times) }\end{array} \\
\end{array}$ & 40.00 & 40.00 & 64.00 & 72.00 & 73.60 & 72.80 & 73.60 & 74.40 & 40.00 & 71.73 & Moderate & Good \\
\hline 4 & $\begin{array}{l}\begin{array}{l}\text { ALOS } \\
\text { (days) }\end{array} \\
\end{array}$ & 1.60 & 2.40 & 3.20 & 2.40 & 2.40 & 1.60 & 1.60 & 1.60 & 2.00 & 2.13 & Moderate & Moderate \\
\hline 5 & GDR $(\%)$ & 3.20 & 2.40 & 4.00 & 3.20 & 4.00 & 3.20 & 3.20 & 3.20 & 2.80 & 3.47 & Good & Good \\
\hline 6 & NDR (\%) & 1.15 & 0.62 & 1.58 & 0.98 & 0.90 & 0.86 & 0.82 & 0.70 & 0.88 & 0.97 & Good & Good \\
\hline
\end{tabular}

Source: Queen Hospital (2008-2015)

From the data above, it shows that the non-financial performance of Queen Hospital is considered good for this BOR indicator either in the period before BLU or period after BLU. Despite the downturn after gaining BLU, the BOR value has proven to be consistent with the criteria set by the Ministry of Health of the Republic of Indonesia, which is between $60 \%$ $85 \%$. The good BOR score also indicates that the number of treated patients does not exceed the available bed capacity at Queen Hospital.

The indicator of TOI of Queen Hospital in the period before BLU still cannot be categorized because it has not fulfilled the criteria/standard set for TOI whereas the period after BLU can be categorized as 'good'. This result shows that the utilization of bed in Queen Hospital is efficient. In the period after BLU, the bed is not used averagely in 1 day and in the period before BLU the average day in which the bed is not used is less than 1 day.

The indicator BTO of Queen Hospital in the period before BLU and period after BLU cannot be categorized as 'good' because they do not meet the standard that has been set. This indicates that the average efficiency level of the use of beds in a year is still not good. Indirectly. The high score of BTO is influenced by the increasing number of inpatient Queen Hospital. This ratio compares the number of patients discharged (live and dead) compared to the number of beds. The more the number of inpatients. the more the number of discharged patients.

The ALOS of Queen hospital is not yet good. ALOS is categorized is bad if the score is around 3 days. The standard for hospital service performance measurement for ALOS is 6-9 days. Since the ALOS cannot be categorized as 'good'. Queen hospital performance is not efficient and cannot give a good quality service. 
The GDR of Queen hospital is generally good because it sits within the standard despite the score is bigger after gaining a BLU. The NDR of Queen Hospital also already meets the criteria. The standard of hospital service performance measurement for NDR is less than 25 patients died for every 1000 patients. In general, the main cause of this high NDR is almost the same as the case for GDR which is the care service is considered to have met the standard so that the death rate becomes low. This NDR number can better reflect the quality of service at the hospital because the NDR rate is based on the number of deaths over 48 hours. Unlike the GDR which is based on the total number of all deaths that often cause bias. Many patients died before 48 hours of treatment.

\section{DISCUSSIONS}

\section{Performance of the Local Government-Owned Hospitals Before and After BLU}

The results of this study are in accordance with the results of a research by Surya (2015) which shows that the trend of assets, accounts receivable, debt, equity, revenue, expenses and profit after BLU tend to increase, and the financial performance after BLU experienced improvement compared to before BLU on the aspects of liquidity and solvency while the profitability, cost recovery rate and the independence level decreased after gaining a BLU. The non-financial performance, which is measured by BOR. TOI, and NDR, after bcoming BLU is much different, compared to that of before BLU, but the scores of BTO. ALOS. and GDR after BLU are far above the criteria/standard of hospital service performance.

The result of this study is consistent with the results of previous research conducted by LC Rawung and Sholihin (2017) which showed that puskesmas (Indonesian health centre)s that have not implemented the PPK-BLUD show better performance than the puskesmas that already became a BLU. Factors affecting the performance of puskesmas in the application of PPK-BLUD are human resources, facilities of infrastructure, and support from health office, local government and legislative institution. The implementation of PPK-BLUD enables puskesmas to improve its revenue by improving their services and promoting the efficiency and effectiveness of spending.

The result of this study is in accordance with the results of previous studies conducted by Nadilla and Fahlevi (2016) which indicates that hospitals are unable to present comprehensive accounting information because the financial statements are generated from different bases of actual financial reporting while the budgets are cash bases, the human resources are not capable, and the management is not committed to the application of the BLUD concept as a business entity.

Another contributing factor in the achievement of financial performance is due to lack of socialization and training on financial report following the Regulation of the Minister of Home Affairs No.61 of 2007 on Public Service Agency. The result of this study is in accordance with the results of research by Amalia (2015) which stated that no significant differences in financial performance before and after BLUD.

Lack of understanding in providing facilities and services to patients can be another contributing factor. The result is in accordance with the results of research conducted by Amintasih (2010) which stated that the quality of service in Karanganyar General Hospital is assessed from three indicators, namely service procedures. officers capability, and service facilities either as BUMD (local government-owned enterprise) or BLUD which do not show any significant change. 
In addition, the service factor to the community is considered no change. This is due to lack of understanding in providing facilities and services to patients. The results of this study are in accordance with the results of research conducted by Amintasih (2010) which states that the quality of service in Karanganyar General Hospital is assessed by three indicators, namely service procedure, officer ability, and service facility at the time as BUMD and BLUD do not show any significant change.

\section{CONCLUSIONS}

Based on the descriptions that have been disclosed in the discussion, some conclusions can be taken as an answer to the main issues rose in this study, namely:

1. Based on the trend analysis, the value of assets, accounts receivable, debt, Equity, revenue, expenses and profit of King Hospital and Queen Hospital after gaining a Public Service Agency tend to increase. The financial performance of both hospitals after gaining a BLU has increased compared to before becoming a BLU on the aspects of liquidity and solvency. While profitability, cost recovery rate and level of independence decreased after gaining a BLU.

2. The Non-financial performance of King Hospital and Queen Hospital after gaining aBLU is relatively the same if compared to before becoming a BLU. In this case, the BOR. TOI and NDR have met the criteria/standard of hospital service performance measurement as stipulated by the Ministry of Health of the Republic of Indonesia. So the performance of these aspects is considered 'good'. While the BTO. ALOS and GDR after gaining a BLU are still considered not meet the criteria/standards of hospital service performance measurement set by the Ministry of Health of the Republic of Indonesia.

\section{SUGGESTIONS}

From the results of this study, the authors can provide suggestions that include:

1. Both hospitals are required to be more transparent and accountable in the management of financial resource by increasing revenue and managing operational costs efficiently and continuously improving the quality of service so that the hospital performance in line with the implementation of the Public Service Agency.

2. For further research, related to the implementation of the Public Service Agency hospitals should examine the aspects of consumer satisfaction and service performance of the hospital to obtain a better picture about the performance of the hospital with the status of Public Service Agency.

\section{LIMITATIONS}

This research limitation might be in term of time. Ideally, this study should be conducted over a longer timeframe to obtain a more comprehensive understanding of the process before and after gaining a Public Service Agency at the Local Government Hospitals.

To overcome these limitations, further research can be done by incorporating observation methods to produce a more concrete picture of financial performance and non-financial performance of the hospital service performance before and after gaining a Public Service Agency. Future research can also be done by developing a research focus and incorporating 
all aspects of financial performance such as liquidity and solvency level in order to obtain a more comprehensive understanding of financial performance before and after gaining a BLU.

\section{REFERENCES}

Amintasih, S. Y. (2010). Dampak perubahan status Rumah Sakit Umum Daerah (RSUD) terhadap kualitas pelayanan (Studi di Rumah Sakit Umum Daerah Kabupaten Karanganyar). Universitas Sebelas Maret.

Direktorat Pembinaan Pengelolaan Keuangan Badan Layanan Umum (PPK BLU). (2014). Frequently ask questions badan layanan umum. Jakarta: Direktorat Jenderal Perbendaharaan Kementerian Keuangan Republik Indonesia.

Direktorat PPK BLU. Implementasi pengelolaan keuangan badan layanan umum (2009).

Fahlevi, H. (2014). The Innovation of the Role of Accounting in Public Hospitals- Lessons Learned from Hospital Financing Reformsin Indonesia and Germany. Disertasi. German University of Administrative Sciences Speyer.

Fahlevi. H. (2016). Understanding why the role of accounting is unchanged in Indonesian public hospitals. Journal of Accounting and Organizational Change, 12(2). 203-222

Jurnali, T., \& Siti-Nabiha, A. K. (2015). Performance Management System for Local Government: The Indonesian Experience. Global Business Review, 16(3), 1-13.

Lembaga Administrasi Negara (LAN). (2003). Pedoman penyusunan dan pelaporan akuntabilitas kinerja instansi pemerintah. Jakarta: Lembaga Administrasi Negara.

Munawir, S. (2007). Analisa Laporan Keuangan. Yogyakarta: Liberty.

Rawung, L.C., \& Sholihin, M. 2017. Does Extended Autonomy of Public Service Agency Lead to A Better Performance? A Case of Indonesia Community Health Centers. Jurnal Dinamika Akuntansi dan Bisnis, 4(2). 231-248

The Republic of Indonesia. Regulation of the Director General of Treasury No. PER$50 / \mathrm{PB} / 2007$ about the guidance on the implementation for the management of non-tax state revenue (PNBP) by the work unit of government agencies applying the financial management of public service agencies (PK-BLU).

The Republic of Indonesia. Regulation of the Minister of Home Affairs No. 13 of 2006 on the guidelines for the management of regional finances (2006). Indonesia.

The Republic of Indonesia. Government Regulation No. 23/2005 on the management of public service agencies (2005).

The Republic of Indonesia. Minister of Health of the Republic of Indonesia No. 129/ Menkes/SK/II/2008 on minimum standards for hospital service (2008).

Sobandi, B., \& Artyasa, U. S. (2006). Desentralisasi dan tuntutan penataan kelembagaan daerah. Bandung: Humaniora.

Sugiyono. (2012). Metode penelitian kuantitatif. kualitatif dan R\&D. Bandung: Alfabeta.

Sugiyono. (2014). Metode penelitian kuantitatif. kualitatif dan $R \& D$. Bandung: Alfabeta.

Surya, S. K. (2015). Analisis kinerja keuangan dan non keuangan rumah sakit umum daerah dr. Haryoto Lumajang sebelum dan sesudah implementasi badan layanan umum. Artikel Ilmiah Mahasiswa. 1-9.

Waluyo, B. (2014). Analisis permasalahan pada implementasi pola pengelolaan keuangan badan layanan umum. Jurnal Infoartha. 3. 27-38. 